\title{
State of the Art on Cactus Additions in Alkaline Media as Corrosion Inhibitors
}

\author{
A. A. Torres-Acosta, ${ }^{1,2}$ W. Martínez-Molina, ${ }^{3}$ and E. M. Alonso-Guzmán ${ }^{3}$ \\ ${ }^{1}$ Construction Materials Laboratory, Universidad Marista de Querétaro, Marte No. 2, Colonia Centro, 76000 Querétaro, QRO, Mexico \\ ${ }^{2}$ Vehicle Engineering and Structural Integrity Coordination, Instituto Mexicano del Transporte, km 12 Carretera Querétaro-Galindo, \\ 76703 Sanfandila, QRO, Mexico \\ ${ }^{3}$ Materials Laboratory, Facultad de Ingeniería, Universidad Michoacana de San Nicolás de Hidalgo, 58030 Morelia, MICH, Mexico
}

Correspondence should be addressed to A. A. Torres-Acosta, atorres@imt.mx

Received 29 February 2012; Accepted 20 May 2012

Academic Editor: Facundo Almeraya

Copyright ( $) 2012$ A. A. Torres-Acosta et al. This is an open access article distributed under the Creative Commons Attribution License, which permits unrestricted use, distribution, and reproduction in any medium, provided the original work is properly cited.

\begin{abstract}
This research in progress includes results on the corrosion performance of reinforcing steel in alkaline media when two different dehydrated cacti (Opuntia ficus-indica-Nopal-and Aloe Vera) were used as additions in pH 12.5 and 13.3 solutions and in concrete. The dehydrated cactus addition was mixed at different concentrations by either solution or cement mass $(0.10 \%, 0.25 \%$, $0.5 \%, 1.0 \%$, and 2.0\%). Half-cell potentials and LPR measurements were performed at different time periods to characterize the possible corrosion inhibiting effect of the cactus additions tested in such alkaline media. Results showed good corrosion inhibiting effect of dehydrated Nopal on reinforcing steel, in all tested solutions, when chloride ions are present. Aloe Vera did show also corrosion inhibiting improvements in some extent. The addition of such cactus led to an apparent formation of a denser and more packed oxide/hydroxide surface layer on the steel surface that decreased corrosion activity. This oxide/hydroxide layer growth was confirmed by microscopic evaluation of the metal surface layer performed at the end of the research program. The preliminary findings suggest that adding Nopal at concentrations between $1 \%$ and $2 \%$, by mass, might be suitable for durability enhancing applications in alkaline media, especially in concrete structures.
\end{abstract}

\section{Introduction}

Corrosion inhibitors are widely used in concrete, where conventional formulations often include species (such as nitrite or benzoate) that have significant toxicity [1]. As a result, they are being scrutinized by environmentalists and could be stopped from being used in the near future since they are significant biohazards and pollutants.

Some researchers consider the use of the simple amino acids alanine, glycine, and leucine as corrosion inhibitors for carbon steel in hydrochloric acid [1]. Natural amino acids are being tested as corrosion inhibitors in different laboratories around the world $[1,2]$. From those, the ones extracted from cactus plants are the most promising ones [2].

Opuntia ficus-indica (OFI, known in Mexico as Nopal) grows in large thickets in semi- and arid environments. Originally native to Mexico, today the cactus is commercially grown in Mexico, Chile, Argentina, Morocco, Italy, and parts of California, Texas, and Florida [3].

As presented elsewhere, Nopal contains several amino acids and sugars [3-5]. Also it contains some minerals such as calcium, potassium, and sodium [3-5]. The presence of such minerals in this botanical product resulted in a longterm stable performance of this products in a highly alkaline media.

The present investigation presents results on the corrosion performance of reinforcing steel in alkaline media when natural organic additions such as dehydrated Nopal were added.

\section{Experimental Procedure}

Three alkaline media were used: saturated calcium hydroxide (SCH) solution (with $\mathrm{pH}$ of $\sim 12.5$ ), saturated pore (SP) 
solution (with $\mathrm{pH}$ of $\sim 13.2$ ), and concrete specimens. All three alkaline medias were prepared with and without natural organic addition (dehydrated Nopal or Aloe Vera).

2.1. SCH Solution. The dehydrated Nopal addition was mixed with $\mathrm{SCH}$ solutions at different percentages: 0.5 , 1.0 , and $2.0 \%$ by solution weight. The electrochemical cell included six $10 \mathrm{~mm}$ in diameter reinforcing bars (also known as rebars). A saturated calomel electrode (SCE) was used as a reference electrode. A stainless steel rod was introduced in the electrochemical cell during corrosion testing. During experimentation, chlorides were added to the solution at a $0.04 \mathrm{M}$ concentration after half-cell potential stabilization ( $\sim 21$ days after rebar immersion).

2.2. SP Solution. In the SP solutions, the dehydrated Nopal was added in percentages of $0.1,0.25,0.5,1.0$, and $2.0 \%$ by solution weight. During experimentation, chlorides were added to both solution types at a $0.04 \mathrm{M}$ concentration after half-cell potential stabilization ( $\sim 60$ days after rebar immersion). The electrochemical cell included four reinforcing bars (10 $\mathrm{mm}$ in diameter). The same reference and counter electrodes as in $\mathrm{SCH}$ solutions were used during corrosion testing.

2.3. Concrete. Ten $5 \times 10 \times 20 \mathrm{~cm}$ prisms were fabricated reinforced with two $10 \mathrm{~mm}$ in diameter reinforcing bars. The specimens included an activated titanium/titanium oxide internal reference electrode (IRE). Two prisms were fabricated without botanical additions (controls), four were with Nopal additions (two prisms were fabricated with $1 \%$ and two with 2\%), and four with Aloe Vera additions (the same number and percentages as Nopal prisms). The concrete mixture properties are presented elsewhere [5]. To introduce in the concrete chloride contamination, wet-dry cycles procedure was implemented by partial immersion of the concrete specimen in $3.5 \%$ chloride contaminated solution (only one rebar was subjected to these wet-dry cycles). The wet stage lasted one week and the dry stage three weeks, giving ponding cycles of one month each. A second set of twenty-four concrete prisms with the same dimensions and embedded electrodes was fabricated to corroborate results of the first set of specimens. In this case all the concrete prism was submerged in a $3.5 \%$ chloride contaminated solution. The concrete mix used to fabricate the specimens consisted of ordinary Portland cement (OPC, cement content $\left.197 \mathrm{~kg} / \mathrm{m}^{3}\right)$, crushed dolomite as coarse aggregate (10 mm maximum nominal size), silica sand as fine aggregate, and a w/c ratio of 0.50 . A special mixture was prepared with puzzolanic cement (PPC, same content) as another control mixture, without Nopal additions. The addition amounts were changed from the first set and included $0.25 \%, 0.50 \%$, and $1.0 \%$ by cement weight ( $\% \mathrm{cw})$. Only Nopal additions were used for this second set of concrete specimens. More details on the concrete mixture properties and experimental procedure are presented elsewhere [6].
2.4. Electrochemical Characterization. To characterize the corrosion inhibiting effect of such natural additions on the steel rebar, half-cell potential and linear polarization resistance (LPR) measurements were performed at different time periods. Potential measurements in the solution cells were measured versus a saturated calomel electrode (SCE) placed inside each cell. For concrete specimens, the measurements were performed using the activated titanium IRE as the reference, and the values were converted into a known reference electrode scale such as a saturated copper/copper sulfate (CSE) electrode. A Gamry's Reference 600 potentiostat was used to measure the apparent polarization resistance $\left(R_{P}\right)$ values of the rebar during all stages. The potentiostat impressed potential was varied from the open circuit potential (OCP) in the cathodic direction, by an amount of $20 \mathrm{mV}$ with a scan rate of $0.05 \mathrm{mV} / \mathrm{s}$. The RP value of the rebar was estimated from the slope of the final portion of the potential-current data, which normally was a straight line the last $10 \mathrm{mV}$ of the scan.

\section{Results}

3.1. SCH and SP Solutions. Results to date show a good corrosion inhibiting effect of Nopal on reinforcing steel, in nominal 12,5 SCH and 13,2 ph SP solutions. Results obtained from $\mathrm{SCH}$ solutions are based on the results of a previous investigation performed by the authors [7] and are shown in Figure 1. As observed from the half-cell potential of the control rebar specimens, the values reached passive potentials during the first hours, as compared to the rebars immersed in Nopal-added solutions, which reached similar potential values after almost 20 days of being immersed in such solutions. The arrows shown in the same Figure 1 correspond to the time where chloride contamination was initiated by adding known amount of $\mathrm{NaCl}$ to the electrochemical cell (see Figure 1). As observed from the same figure, after adding chlorides to the solution, no differences were observed between the half-cell potential values of neither control nor Nopal-added solutions.

Figure 2 shows the average polarization resistance $\left(R_{P}\right)$ measurements during the experimental stage (average of six rebars). As observed from data in Figure 2, $R_{P}$ values increase from average $40 \mathrm{k} \Omega / \mathrm{cm}^{2}$ for regular chloride-contaminated $\mathrm{SCH}$ solution, as compared with average $150 \mathrm{k} \Omega / \mathrm{cm}^{2}$ for Nopal-added, chloride-contaminated, SCH solutions. The results shown indicated that Nopal additions inhibit the corrosion activity of reinforcing steel when chloride contamination is present.

Following the study, an additional surface visual survey was performed to the rebars tested in these alkaline solutions by checking the number of active zones present (pits) after disassembling the electrochemical cells at the end of the experimental stage. The results are shown in Figure 3. As observed from the results shown in Figure 3, a well-defined trend was obtained where the Nopal additions acted as a pit inhibitor. This supports the inhibiting action of Nopal in these kinds of chloride-contaminated solutions. 


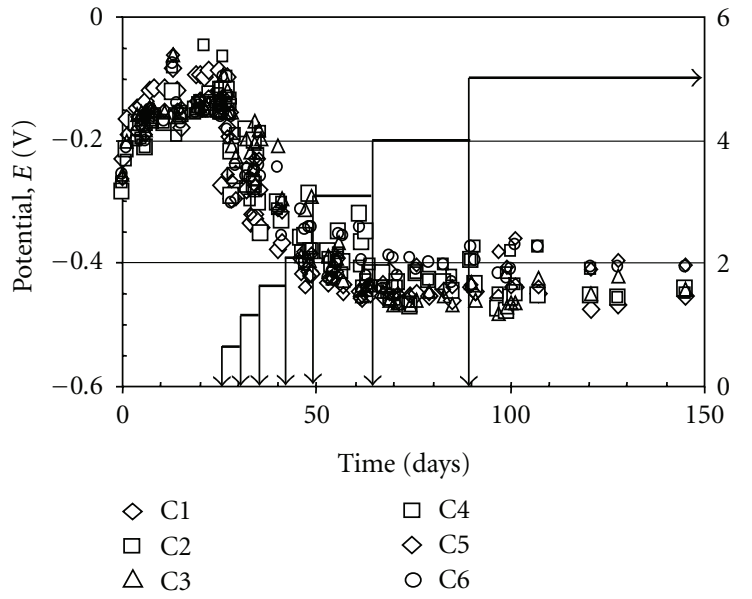

(a) Control

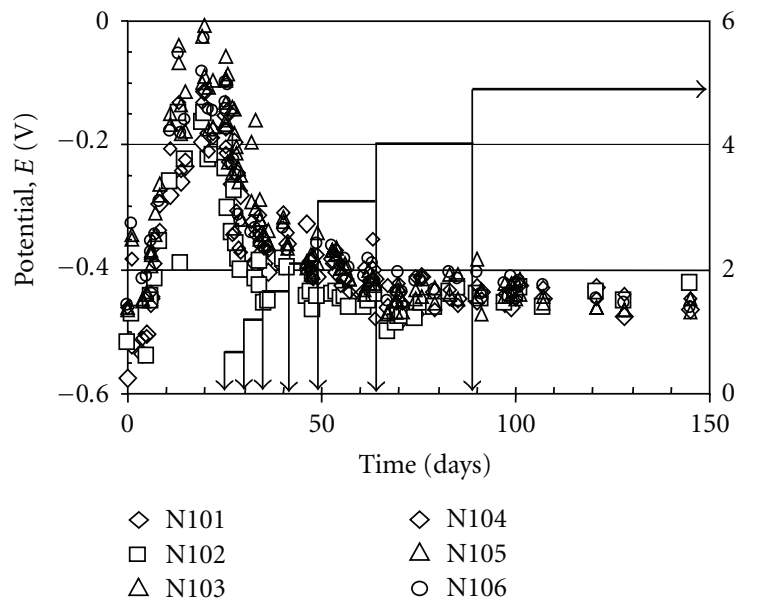

(c) 1.0

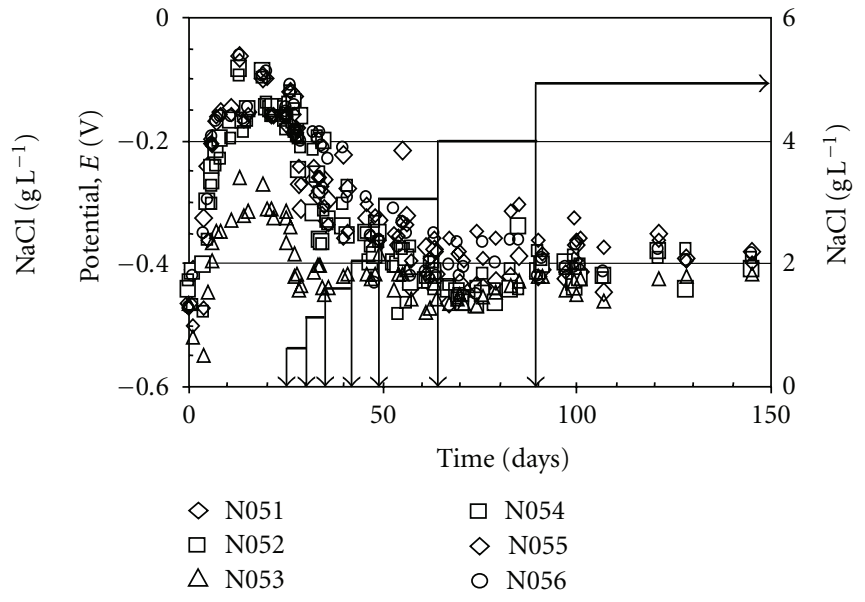

(b) 0.5

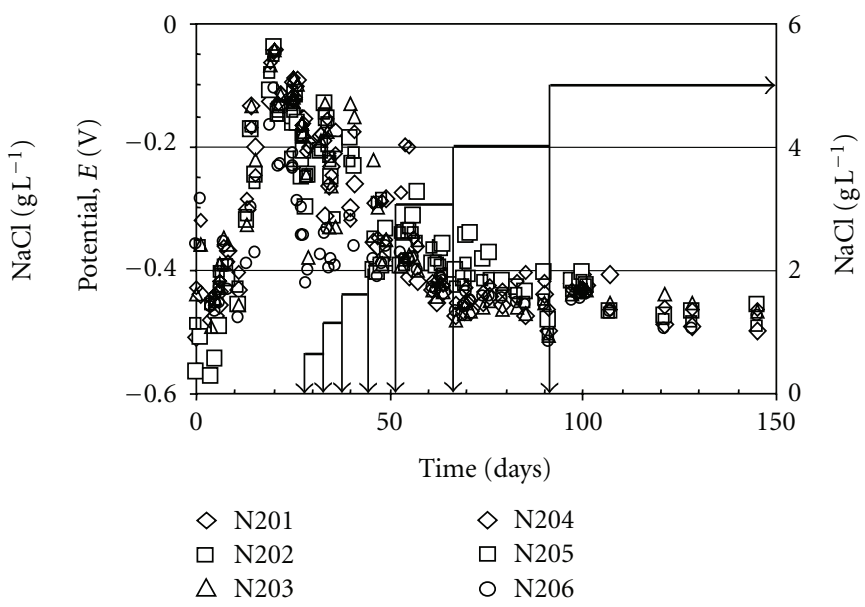

(d) 2.0

FIgURE 1: Half-cell potentials versus time of all SCH solution electrochemical cells [7].

3.2. SP Solution. Similar procedure as that for SCH solutions was followed for SP solution, with the only difference that four rebars were used in each electrochemical cell, as compared to six rebars used in the SCH cells. Values of halfcell potential for each rebar in each SP solution tested are shown in Figure 4.

Considering rebar corrosion activation when the halfcell potential is more negative than $-0,28 \mathrm{~V}$ versus SCE, the time where this value was reached was recorded (defined as time of corrosion initiation, $T_{i}$ ) for each one of the rebars in the electrochemical cell evaluated. A probabilistic representation of such $T_{i}$ values is shown in Figure 5, where the lines represent the accumulative distribution of $T_{i}$ for each solution tested. A well defined trend is observed from Figure 5, where the control rebars in the Nopal-free solution showed smaller $T_{i}$ values (thicker line with black rhomboids). The rest values for Nopal-added solutions did not present a defined trend as a function of the amount of added Nopal, but it is clear that the values of $T_{i}$ increased as compared to the ones for the control electrochemical cell.
3.3. Concrete. Results obtained from the first set of concrete prisms are based on the results of a previous investigation performed by the authors [5]. Figure 6 shows the half-cell potentials as a function of time of typical measurements obtained from no addition, 2\% Nopal, 1\% Nopal, 2\% Aloe Vera, and $1 \%$ Aloe Vera concrete specimen. The data shown in Figure 6 correspond to the potential values from the two rebars from one concrete prism only: one rebar close to the ponding pool and the other away from it. As a result one rebar presented active corrosion potential values, as chlorides reached this rebar depth, and the other rebar stayed passive (potentials more positive than $-0.35 \mathrm{~V}$ versus CSE).

During the curing stage, the rebar average potentials were all similar $(\sim-0.2 \mathrm{~V}$ versus CSE) regardless of concrete type (see Figure 6). At first stabilization stage the concrete prisms were moved to a dryer environment from $\sim 95 \%$ $\mathrm{RH}$ in the curing chamber to $\sim 60 \% \mathrm{RH}$ in laboratory environment. This gradual change from high to intermediate humidity changed the half-cell potential to more positive values $(\sim+0.05 \mathrm{~V}$ versus CSE). During few minutes after 


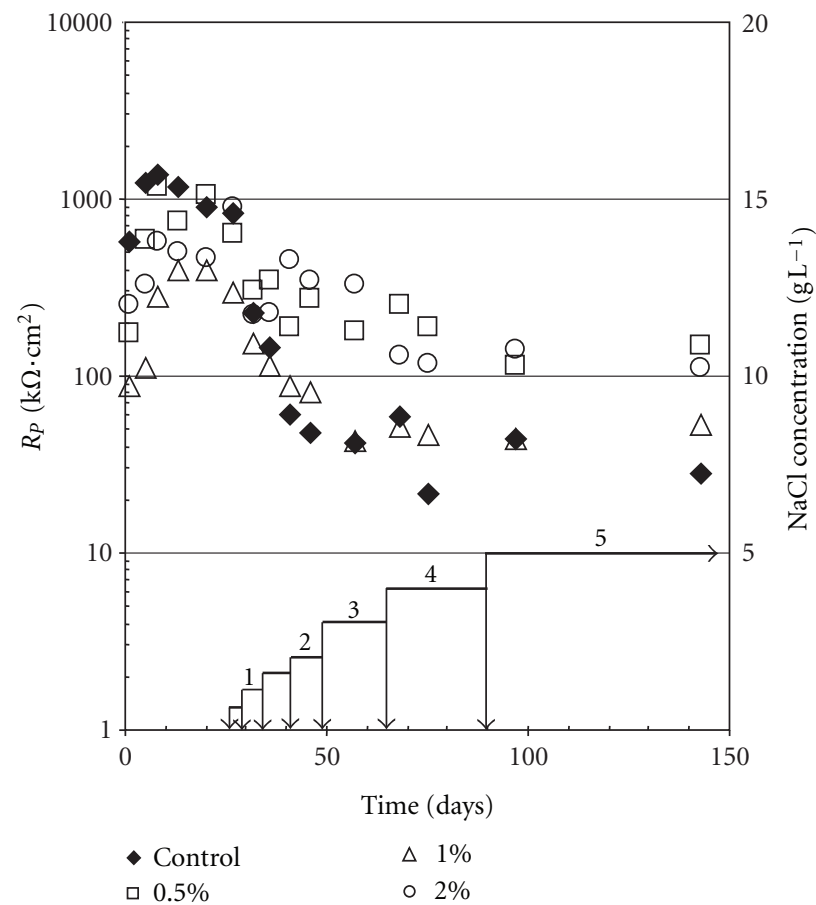

FIGURE 2: Average polarization resistance $\left(R_{P}\right)$ values for all SCH electrochemical cells evaluated [7].

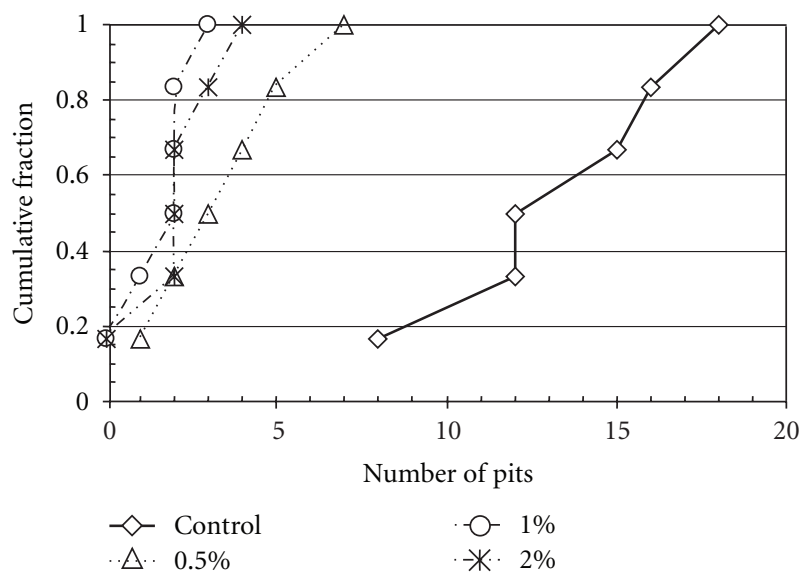

FIGURE 3: Cumulative fraction of number of pits formed after the end of the experiment for all SCH electrochemical cells [7].

starting the first ponding, the rebar half-cell potential, closest to the ponding pool, decreased few mileivolts $(\sim 0.05 \mathrm{~V}$ more negative), as compared to the rebar away from the ponding pool tha stayed in the same range of potential values.

Based on ASTM C876 criterion where corrosion activity of rebar in concrete might be initiated when the half-cell potential is $\leq-0.35 \mathrm{~V}$, Figure 6 presents a threshold line which separates passive and active behavior of typical rebars in concrete. Thus, the time of corrosion initiation (or $T_{i}$ ) is estimated as the time when the half-cell potential value of the rebar is below such line. Table 1 lists the times of corrosion initiation of all rebars closer to the ponding pool for each concrete cell. Based on the results obtained with this first set (average of two specimens only), there is an apparent increase in time $T_{i}$ from about 3.5 days (in average) for the control specimens (no additions) to almost 7 and 18 days (in average) after ponding started for Aloe Vera and Nopal additions, respectively.

Since the concrete cover $(2 \mathrm{~cm})$ used is a high w/c ratio (0.7), the porosity of such concrete is high. Thus, the time of corrosion initiation is quite small as compared to other investigations with $4 \mathrm{~cm}$ more dense cover concrete (low porosity with $\mathrm{w} / \mathrm{c}<0.4)$ where the activation took place after 3 to 5 months [8].

Figure 7 shows the average $R_{P}$ data (average of two) as a function of time for all mixtures tested. As observed in Figure 7, the average $R_{P}$ values for concrete without additions in all stages were smaller than the average observed 


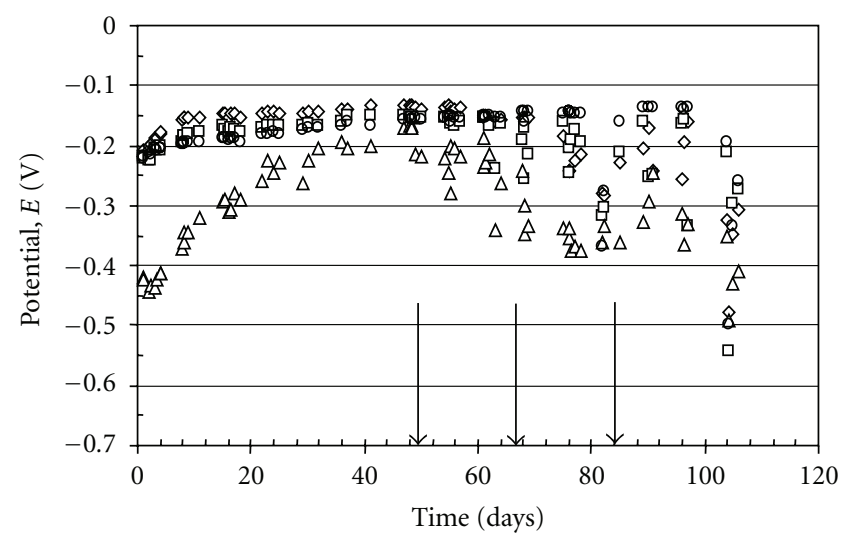
$\diamond \mathrm{C} 1$
$\square \mathrm{C} 2$

\begin{abstract}
$\triangle \mathrm{C} 3$
\end{abstract}
O C4

(a) Control

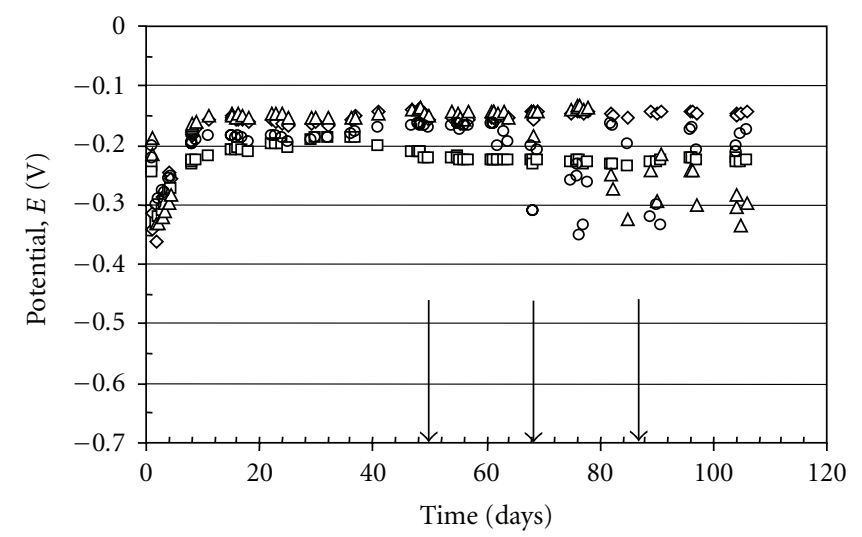

$\begin{array}{ll}\diamond & \mathrm{N} 025-1 \\ \square & \mathrm{N} 025-2\end{array}$

$\triangle \mathrm{N} 025-3$

○ N025-4

(c) 0.25

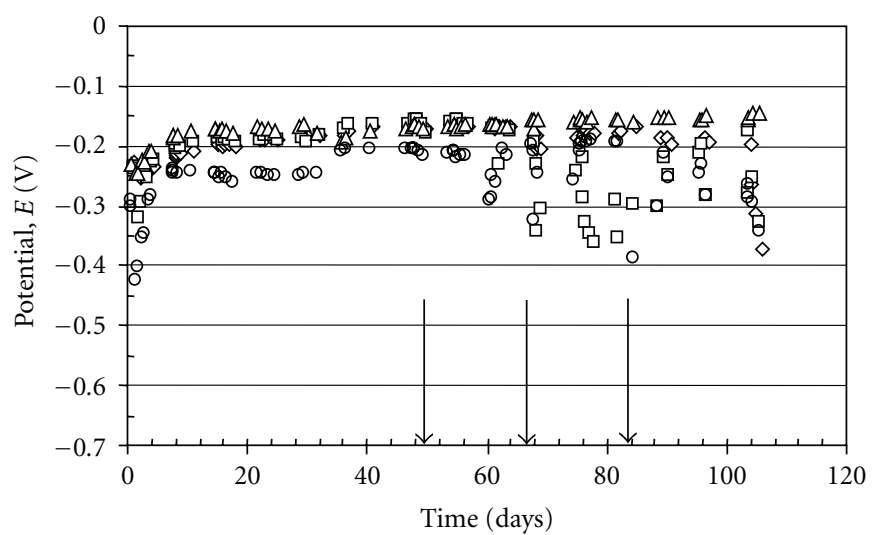
$\diamond \mathrm{N} 010-1$
$\triangle \mathrm{N} 010-3$
N010-2
o N010-4

(b) 0.10

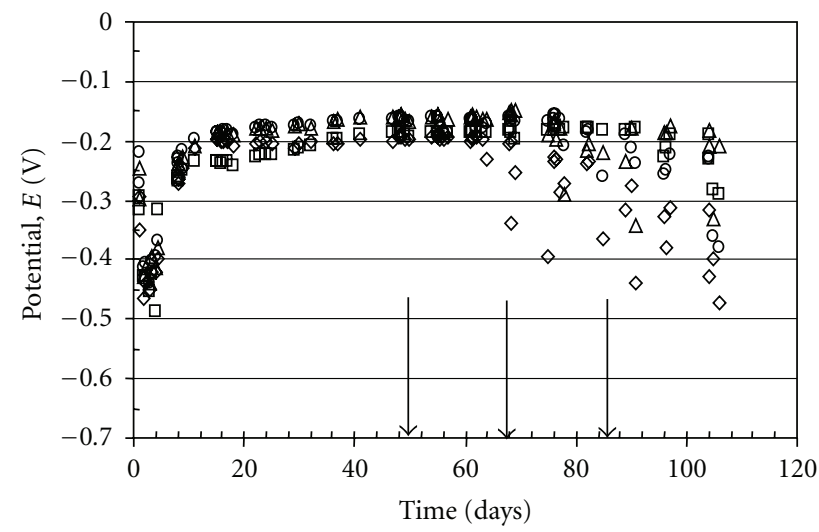
$\diamond \mathrm{N} 050-1$
$\triangle \mathrm{N} 050-3$
$\square \mathrm{N} 050-2$
O N050-4

(d) 0.50

FIGURE 4: Half-cell potentials versus time of all SP solution electrochemical cells.

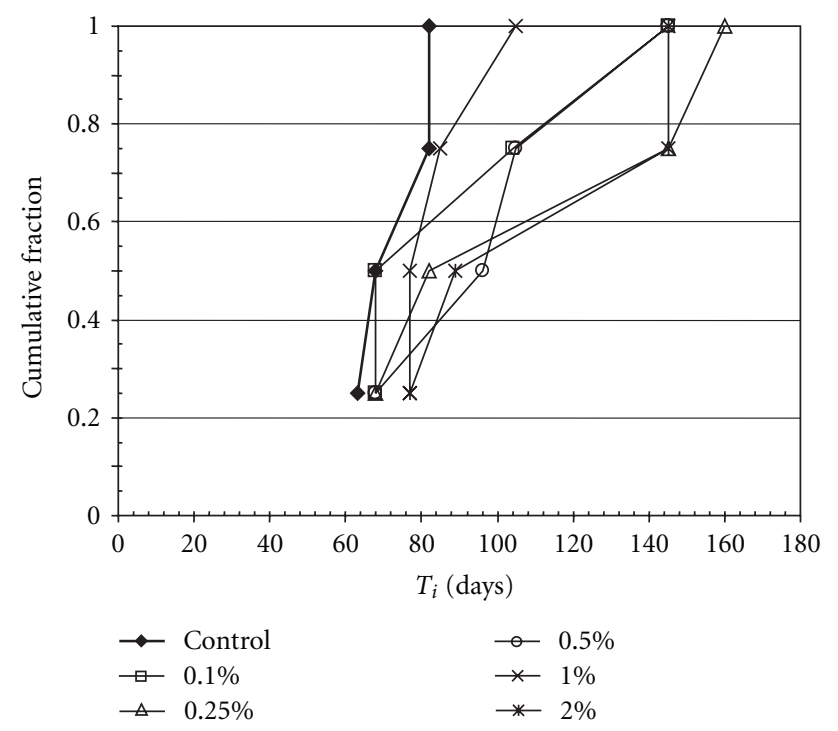

FIGURE 5: Cumulative fraction of the time of corrosion initiation $\left(T_{i}\right)$ for all SP electrochemical cells. 

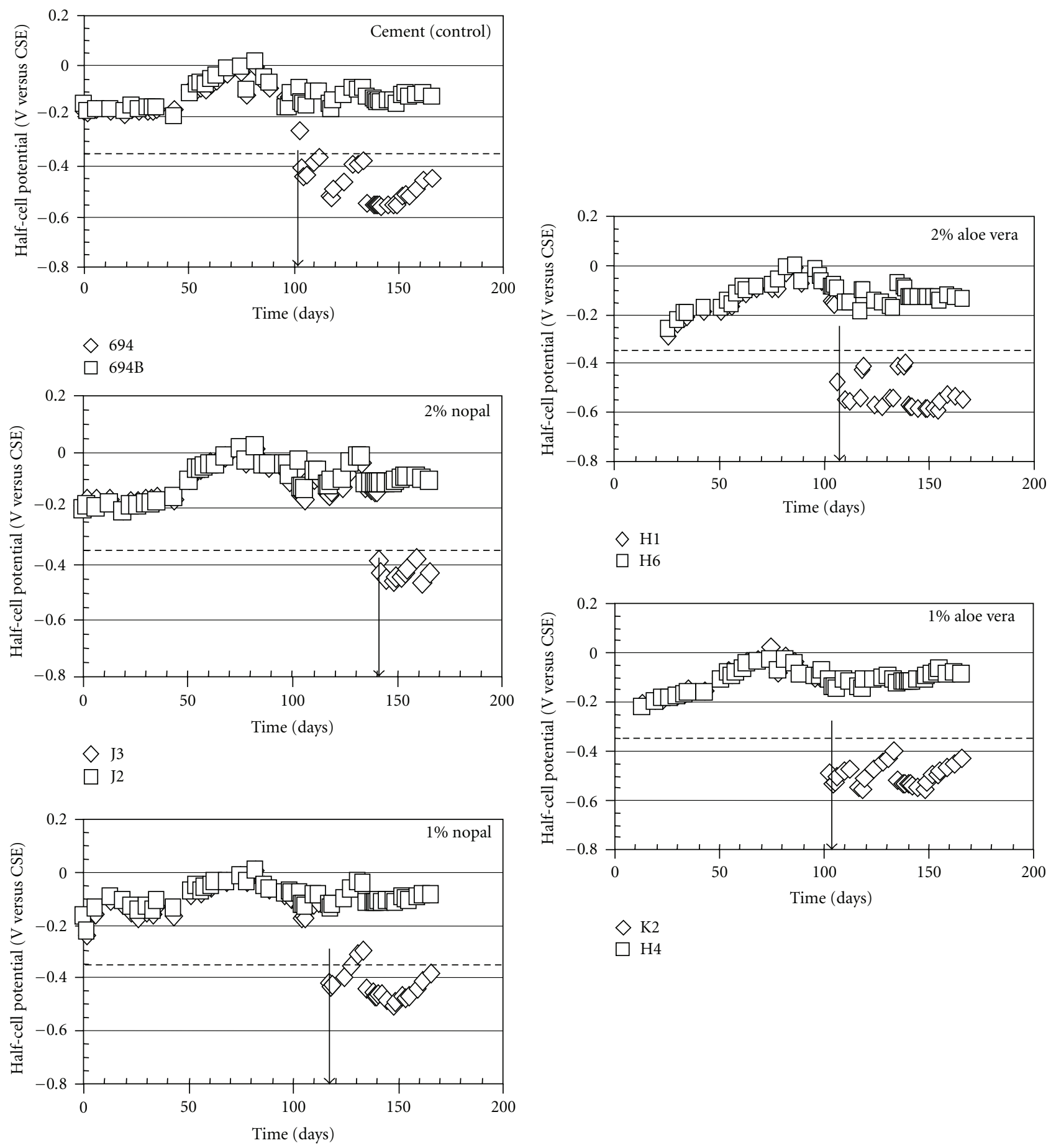

$\diamond \mathrm{H} 9$

$\diamond \mathrm{H} 1$

$\square \mathrm{H} 6$

$\diamond \mathrm{K} 2$

$\square \mathrm{H} 4$

$\square$ K3

FIgURE 6: Half-cell potentials versus time of all concrete prisms tested. The arrow represents the time of corrosion initiation (or $T_{i}$ ).

in concrete with additions. Special emphasis could be taken to the average data for $2 \%$ Nopal replacement concrete, where the $R_{P}$ estimate was high $\left(\sim 2000 \mathrm{~K} \Omega-\mathrm{cm}^{2}\right.$ average $)$ up to 140 days of testing time (after the 3 rd wet cycle). This will give smaller apparent corrosion rates of steel in chloridecontaminated concrete when Nopal and Aloe Vera are added to the concrete.
Based on the results obtained with these concrete prisms, a second set of specimens were fabricated with similar geometry and number of electrodes embedded in the concrete (two steel rebars and one titanium IRE). Figure 8 shows the half-cell potentials as a function of time of typical measurements obtained from no addition (OPC only), $0.25 \%$ Nopal, $0.5 \%$ Nopal, and 1\% Nopal concrete 


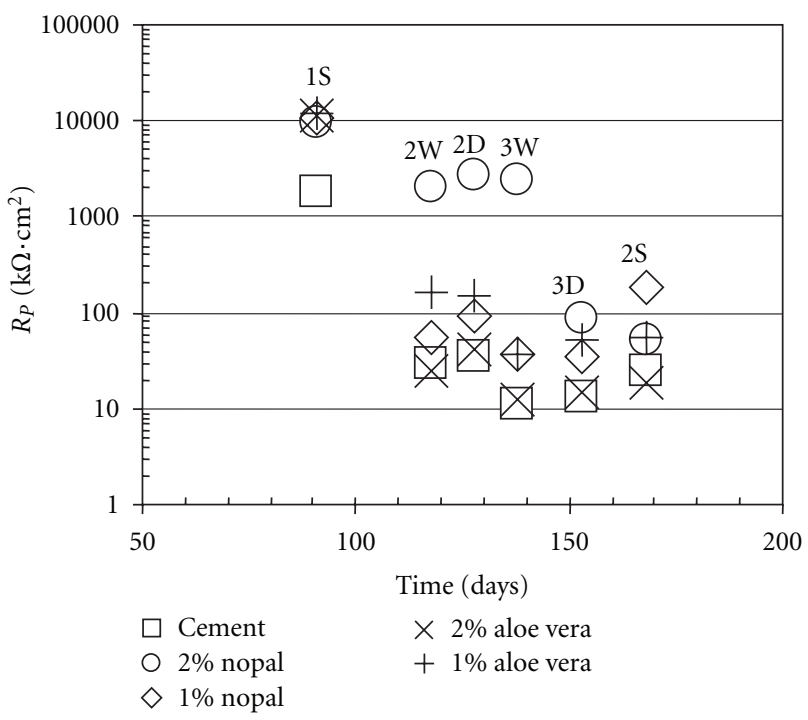

FIGURE 7: Average polarization resistance $\left(R_{P}\right)$ values versus time for all concrete electrochemical cells evaluated.
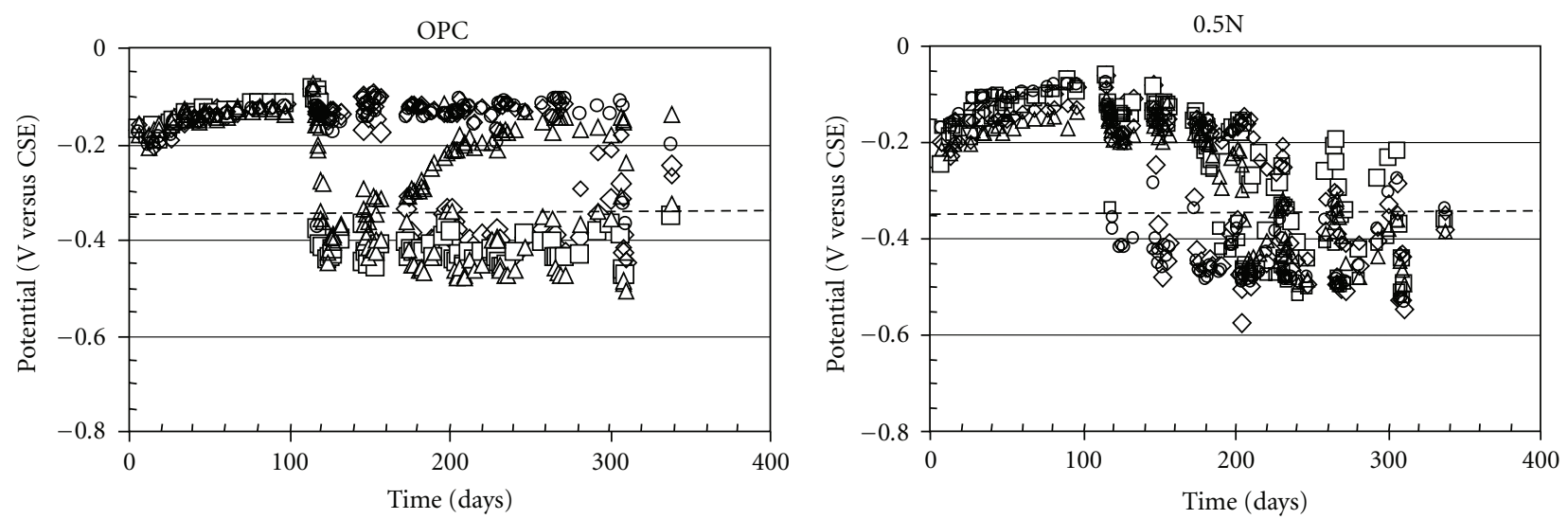
$\diamond 544 \mathrm{~A}$
$\triangle 542 \mathrm{~A}$
$\square 544$
$\diamond 541$
$\triangle 542$
$\circ 541 \mathrm{~A}$

$\diamond 559 \mathrm{~A}$

$\diamond 565 \mathrm{~A}$

$\square 559$
$\triangle 565$

$566 \mathrm{~A}$

(a)

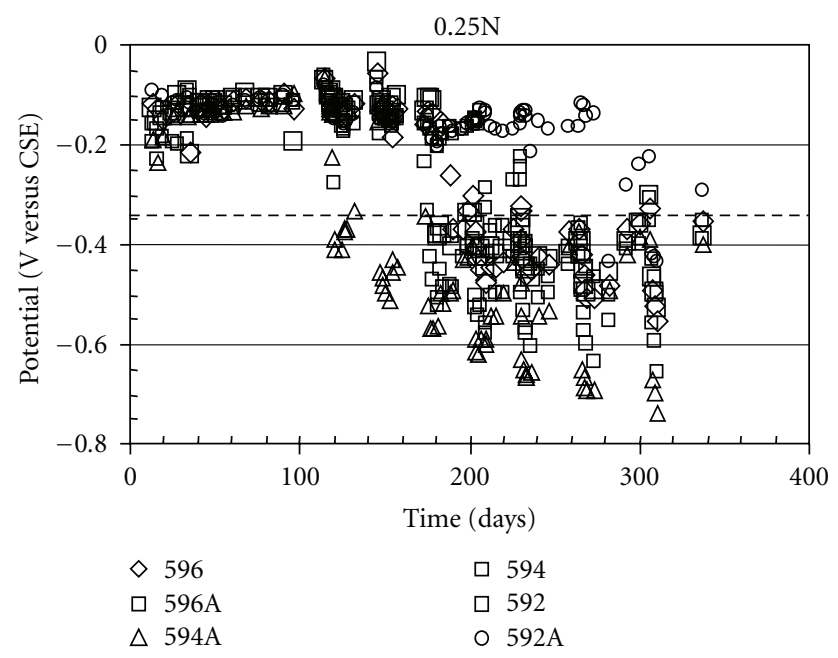

(c)

(b)

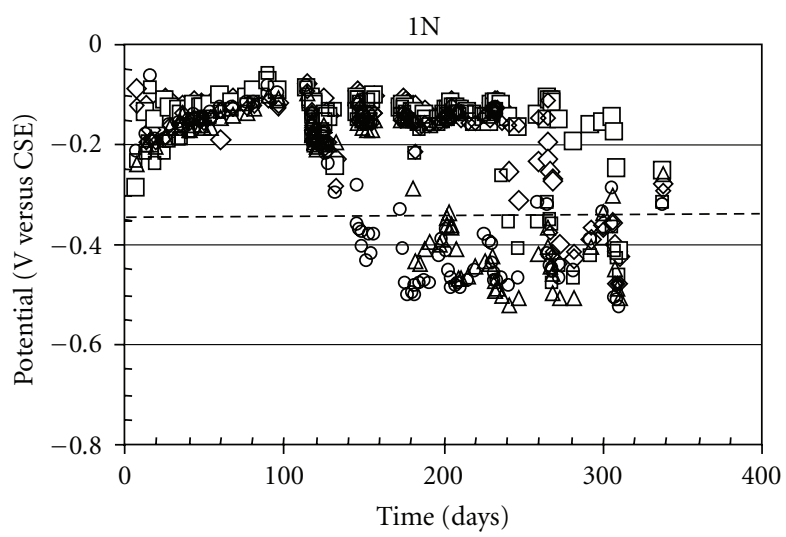
$\diamond 545 \mathrm{~A}$
$\diamond 548$
$\square 545$
ㄷ55
$\triangle 548 \mathrm{~A}$
○ $555 \mathrm{~A}$

(d)

FIGURE 8: Half-cell potentials versus time of all second set of concrete specimens tested. 


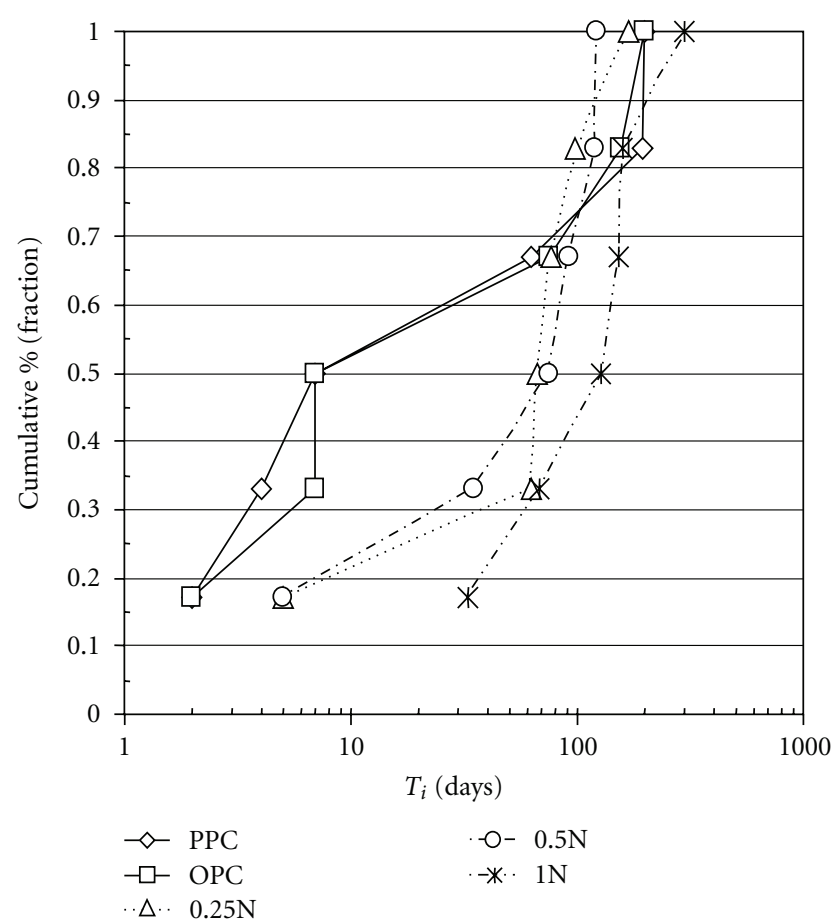

FIgURE 9: Time for corrosion initiation, $T_{i}$, for all specimens tested in the second set.

TABle 1: Time of corrosion initiation $\left(T_{i}\right)$ for each rebar tested in the first set of prisms.

\begin{tabular}{lcc}
\hline $\begin{array}{l}\text { Specimen } \\
\text { Designation }\end{array}$ & $\begin{array}{c}T_{i} \\
\text { Days }\end{array}$ & $\begin{array}{c}\text { Average } T_{i} \\
\text { Days }\end{array}$ \\
\hline Control 1 & 2 & 3.5 \\
Control 2 & 5 & \\
Nopal 2\%_1 & 4 & 23 \\
Nopal 2\%_2 & 42 & \\
Nopal 1\%_1 & 6 & 12 \\
Nopal 1\%_2 & 18 & \\
Aloe V 2\%_1 & 4 & 12 \\
Aloe V 2\%_2 & 20 & \\
Aloe V 1\%_1 & 2 & 2.5 \\
Aloe V 1\%_2 & 3 & \\
\hline
\end{tabular}

specimens. No differences were obtained between the results of the two control concrete mixtures, OPC and PPC, and thus the results of PPC are not presented in this investigation.

During the curing stage, the rebar average potentials were all similar $(\sim-0.2 \mathrm{~V}$ versus CSE $)$ regardless of concrete type (see Figure 8). At first stabilization stage the concrete prisms were moved to a dryer environment from $\sim 95 \%$ $\mathrm{RH}$ in the curing chamber to $\sim 65 \% \mathrm{RH}$ in laboratory environment. This gradual change from high to intermediate humidity changed the half-cell potential to more positive values ( $\sim 0.1 \mathrm{~V}$ versus CSE).

Figure 8 inlcudes a dotted horizontal lines which corresponds to the threshhold line which separates passive and active behavior of typical rebars in concrete according, again, to ASTM C876. Thus, the time $T_{i}$ is estimated as the time when the half-cell potential value is below such line. Figure 9 shows the $T_{i}$ values of all rebars tested. Based on the results obtained at the moment, there is an apparent increase in $T_{i}$ values if Nopal is added into the concrete mixture.

Since the concrete cover $(2.5 \mathrm{~cm})$ used has a $0.5 \mathrm{w} / \mathrm{c}$ ratio, the porosity of such concrete is high. Thus, the time of corrosion initiation is quite small as compared to other investigations with $4 \mathrm{~cm}$ more dense cover concrete (low porosity with $\mathrm{w} / \mathrm{c}<0.4$ ) where the activation took place after 3 to 5 months [8], but were higher than the obtained with the first set of specimens with more porous concrete (w/c ratio $\sim 0.7$ ). The $T_{i}$ values for this second set of concrete prisms were higher than the first set, mainlly because the concrete's $\mathrm{w} / \mathrm{c}$ ratio for the first set $(\sim 0.7)$ was higher than the second set of prisms (0.5), therefore, concrete's first set was more porous than concrete's second set

A probabilistic representation of $T_{i}$ values is shown in Figure 9, where the lines represent the accumulative distribution of $T_{i}$ for each concrete mixture tested. A similar trend was observed as from SPS data: the control rebars in the Nopal-free solution showed smaller $T_{i}$ values. The values for Nopal-added concretes in this second set of specimens presented a defined trend as a function of the amount of added Nopal: the higher the Nopal amount, the more the time $T_{i}$. It is also clear that the values of $T_{i}$ increased as compared to the ones for the control electrochemical cell. No apparent differences were obtained with the two control mixtures, OPC and PPC, supporting what was observed from $R_{P}$ test results (not shown in the investigation).

\section{Discussion}

The apparent interaction of Nopal on the steel was the formation of a denser and more packed oxide/hydroxide surface layer, which decreased the corrosion activity of the steel when chlorides were added to the SCH and SP solution afterwards. This oxide/hydroxide layer growth due to Nopal interaction with the reinforcing steel was further confirmed by microscopy evaluation of the metal surface layer performed at the end of the experiment in [7]. It was found also that dehydrated Nopal provides a good protection to steel against pitting corrosion in chloride-contaminated alkaline media.

As observed from results with concrete specimens, the time of corrosion activation was also increased in concrete from few days until some hundreds of days if Nopal was added to the mixture. The preliminary findings suggest that adding dehydrated Nopal at small concentrations (between $1 \%$ and $2 \%$ ) might be suitable for durability enhancing applications in concrete and possibly in all cement-based materials.

\section{Conclusions}

Results showed good corrosion inhibiting effect of dehydrated Nopal on reinforcing steel, in all alkaline solutions tested, when chloride ions are present. Aloe Vera did show 
also corrosion inhibiting improvements to some extent. The addition of such cactus led to an apparent formation of a denser and more packed oxide/hydroxide surface layer on the steel surface that decreased corrosion activity. This oxide/hydroxide layer growth was confirmed by visual surface evaluation of the metal surface layer, from the $\mathrm{CH}$ solution specimens, performed at the end of the research program. The preliminary findings suggest that adding Nopal or Aloe Vera at concentrations between $1 \%$ and $2 \%$, by mass, might be suitable for durability enhancing applications in alkaline media, especially in concrete structures.

\section{Acknowledgments}

The authors are indebted to Instituto Mexicano del Transporte (Mexican Transportation Research Institute) Querétaro, Mexico, for the financial support and research scholarships provided to the Universidad Marista de Queretaro (Marist University of Queretaro) with Contract no. IMT-QCC-33-03. The authors acknowledge Grupo Botanico NAYEC, S.A. de C.V. and NOPALZIN S.A. de C.V. for providing the tested products. Special thanks are due to Jessica Herrera-Núñez Alejandro Perez-Gallardo, and Cesar Celis-Mendoza, undergraduate students from the UNAM (JHN) and Universidad Marista de Queretaro (APG, CCM), for helping with the specimen preparation and monitoring. The opinions and findings in this paper are those of the authors and not necessarily those of the funding agencies.

\section{References}

[1] H. Ashassi-Sorkhabi, M. R. Majidi, and K. Seyyedi, "Investigation of inhibition effect of some amino acids against steel corrosion in $\mathrm{HCl}$ solution," Applied Surface Science, vol. 225, no. 1-4, pp. 176-185, 2004.

[2] A. Y. El-Etre, "Inhibition of aluminum corrosion using Opuntia extract," Corrosion Science, vol. 45, no. 11, pp. 2485-2495, 2003.

[3] C. Sáenz, E. Sepúlveda, and B. Matsuhiro, "Opuntia spp mucilage's: a functional component with industrial perspectives," Journal of Arid Environments, vol. 57, no. 3, pp. 275-290, 2004.

[4] F. M. Goycoolea and A. Cárdenas, "Pectins from opuntia spp: a short review," Journal of the Professional Association for Cactus Development, vol. 5, pp. 17-29, 2003.

[5] A. A. Torres-Acosta, M. Martínez-Madrid, D. C. Loveday, and M. R. Silsbee, "Nopal and aloe vera additions in concrete: electrochemical behavior of the reinforcing steel," in Proceedings of the Symposium New Developments in the Protection of Steel in Concrete, no. 05269, Houston, Tex, USA, April 2005.

[6] A. A. Torres-Acosta, W. Martínez-Madrid, M. G. LomeliGonzalez, and A. Perez-Gallardo, "Cactus-based additions as corrosion inhibitor for reinforcing steel in concrete," Tech. Rep. 328, Instituto Mexicano del Transporte, Queretaro, Mexico, 2009.

[7] A. A. Torres-Acosta, "Opuntia-Ficus-Indica (Nopal) mucilage as a steel corrosion inhibitor in alkaline media," Journal of Applied Electrochemistry, vol. 37, no. 7, pp. 835-841, 2007.

[8] N. S. Berke, M. P. Dallaire, M. C. Hicks, and R. J. Hoopes, "Corrosion of steel in cracked concrete," Corrosion, vol. 49, no. 11, pp. 934-943, 1993. 

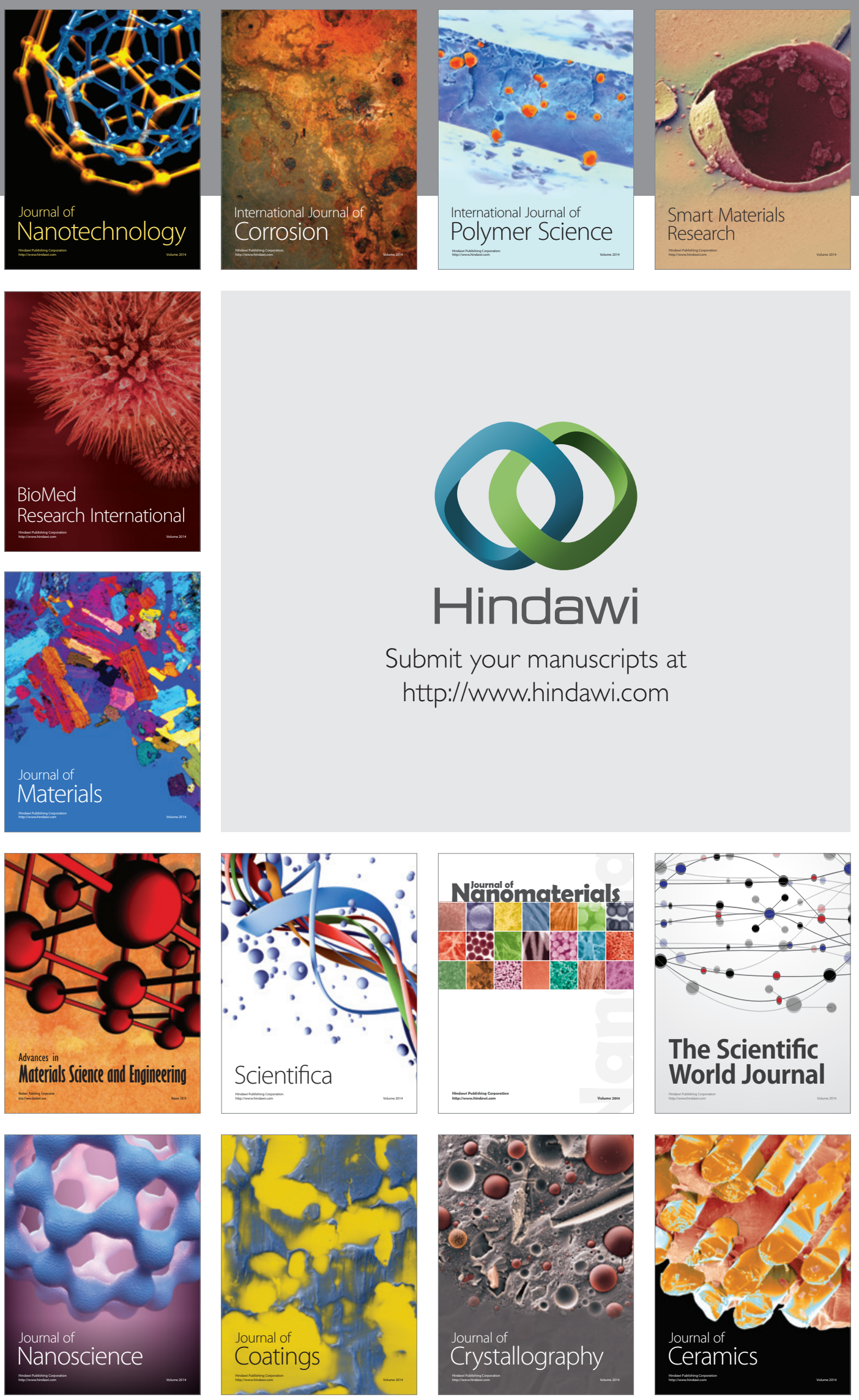

The Scientific World Journal

Submit your manuscripts at

http://www.hindawi.com

\section{World Journal}

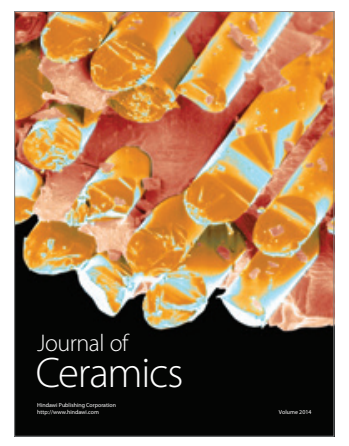

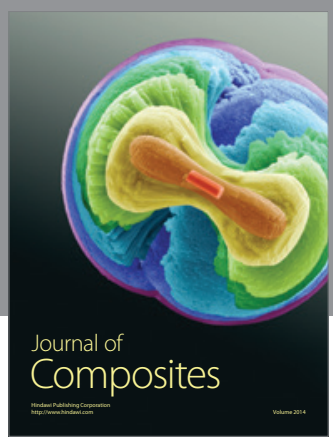
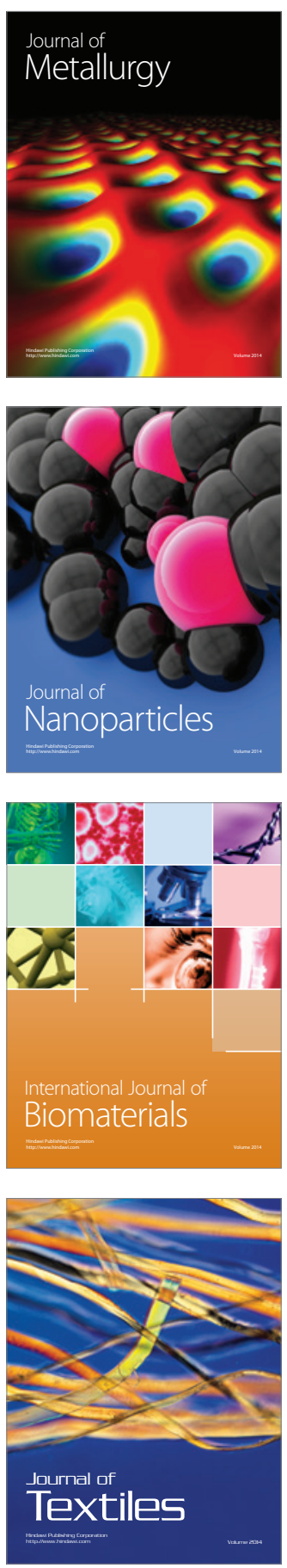